\title{
The Hue and Cry of Campus Climate: Faculty Strategies for Creating Equitable Work Environments
}

\author{
Christine M. Cress \\ Portland State University
}

\section{Jennifer L. Hart}

University of Missouri-Columbia

Quantitative and qualitative data from faculty at a large public research university provide contrasting work life experiences for faculty of color and white faculty. Significant differences are evident regarding teaching and research, institutional priorities, individual goals, job satisfaction, and sources of stress. Specific faculty strategies for creating equitable environments are highlighted.

\section{INTRODUCTION}

$\mathrm{D}$ espite administrative efforts to ensure fairness and enhance diversiry, faculty of color are underrepresented and continue to experience subtle and overt discrimination in the academy (Antonio, 2002; Astin \& Cress, 1998; Finkelstein, Seal, \& Schuster, 1998; Garcia, 2000). Prompted by concerns over high attrition rates for faculty of color, a systematic investigation was conducted to determine elements that enhance or hinder faculty work life at a large public research-intensive university in the southwest. While student demographics had shifted at the institution, the representation of diverse faculty role models continued to decline. Since perceptions of the 
institution are inextricably linked with behavioral outcomes, including faculty retention (Tierney $\&$ Bensimon, 1996), the present study assessed differential faculty experiences in order to solicit strategies to transform the institutional climate.

\section{BACKGROUND LITERATURE}

Recent studies indicate that faculty of color feel marginalized and undervalued in academe (Finkelstein et al., 1998; Garcia, 2000). Turner (2002) suggests that the representation of faculty of color is not only problematical but that creating a critical numerical mass is not enough. Rather, an essential element for faculty of color success is the nature of the response they feel from majority faculty. This includes the subtle and less tangible elements of work life such as attitudes, expectations, and stereotypes that may be manifested as disrespectful remarks and behaviors. Further, the effectiveness of individual agency is diminished for some faculty (e.g., faculty of color, women faculty, gay and lesbian faculty) who may find that asserting their own teaching and research interests into the academic culture may detrimentally impact tenure and promotion (Tierney, 1997; Tierney \& Rhoads, 1993; Turner \& Thompson, 1993).

Faculty of color are often assumed to be experts on issues of race and ethnicity and are frequently called upon by the administration to educate the majority, to teach courses that contribute to a multicultural curriculum, and to speak for all faculty of color on committees (Brown, 2000; Padilla, 1994). These expectations translate into what has been referred to as cultural taxation (Brown; 2000; Padilla, 1994),

to show good citizenship toward the institution by serving its needs for ethnic representation on committees, or to demonstrate knowledge and commitment to a cultural group, which may even bring accolades to the institution but which is not usually rewarded. (Padilla, 1994, p. 26)

Equally burdensome and underrecognized is the hidden workload of student advising (Creamer, 1998; Garcia, 2000; Turner, 2002). While advising is a regular duty of faculty workload, faculty of color often feel the increased onus of informal advising. Students of color tend to seek out faculty of color because they are perceived to better understand their issues (Brown, 2000). Moreover, some faculty of color feel that research and scholarship focused on diversity or ethnic issues is viewed as nonacademic by their white majority 
colleagues (Creamer, 1998; Garcia, 2000; Padilla, 1994) which may detrimentally impact tenure and promotion (Tierney, 1997; Tierney \& Rhoads, 1993; Turner \& Thompson, 1993). Ultimately, increased out-of-class instruction load, coupled with expectations related to cultural taxation, create an environment for faculty of color where there is too much demand for work that is not rewarded and too little opportunity to produce scholarship that is valued (Turner, 2002).

\section{Conceptual Framework}

Wilber (1998) proposes that organizations are best understood by examining individuals and groups across social/psychological and behavioral/procedural dimensions, that are either internal (known but unobservable) or external (observable). These four dimensions are 1) individual beliefs, values, atcitudes, and feelings; 1) individual behaviors; 3 ) institutional or group beliefs, values, attitudes, and feclings; and 4) institutional or group processes and practices (see Figure 7.1). The problem, according to Wilber, is that most leadership and change efforts tend to address only one dimension. Therefore, if we want to fully understand the nature of the academic environment, we must examine the entire complement of realities.

Figure 7.1

An Interactive Organizational Model

\begin{tabular}{lcl}
\hline & Internal & External \\
\hline Individual & Beliefs, values, attitudes, feelings & Behaviors \\
\hline Group or Institution & Beliefs, values, attitudes, & Processes, \\
& feelings (i.e., cultural norms) & practices \\
\hline
\end{tabular}

Adapted from Wilber (1998)

Hurtado, Milem, Clayton-Pedersen, and Allen (1998) supplement Wilber's work by arguing that, historically, institutions have attempted to address diversity issues almost exclusively from a structural perspective (e.g., increasing the numbers of underrepresented individuals). When structural diversity is increased without consideration of other psychological and social dimensions of campus climate, interpersonal conflicts are likely to result. The consequence is that opportunities to sustain diversity are compromised.

Given that most academic leaders and administrators responsible for initiating institutional change are a part of the white majority, it is crucial that we 
understand the various perceptions and experiences of all faculty, but especially those of faculty of color. Existing research on faculty of color suggests that these faculty often face obstacles that make their work life qualitatively different from that of their white colleagues (Astin, Antonio, Cress, \& Astin, 1997; Astin \& Cress, 1998, 2002; Creamer, 1998; Garcia, 2000; Laden \& Hagedorn, 2000; Padilla, 1994; Turner, 2002). This study focused on the psychological and behavioral climates at the institution using models by Wilber (1998) and Hurtado et al. (1998) to guide the analysis. These frames are particularly salient since "only when values and their effect on practice are revealed can change agents begin to transform values and modify practice" (O'Meara, 2002, p. 60).

\section{METHODOLOGY}

To examine campus climate comprehensively, the study design included collection and assessment of both quantitative and qualitative data. The quantitative data allowed for statistical analysis and comparison within the institution across race/ethnicity on a number of issues (e.g., teaching loads, publication numbers, perceptions of discrimination). The qualitative data allowed for purposive samples of faculty to share their experiences at the institution and to offer insights and suggestions for institutional improvement. Thus, the methodology provided for statistical testing of inequities, deeper insights into the daily realities of faculty work life, and the emergence of strategic suggestions for change.

\section{Quantitative Data}

Quantitative data were utilized from the university's participation in the National Survey of College and University Faculty (Higher Education Research Institure [HERI], 1999). This was the fourth in a series of national faculty surveys conducted on a triennial basis by HERI that resulted in 33,785 responses, including 837 from this institution. Statistical testing (chi-square) across gender, tenure, and academic rank indicated that the sample mimics the institution's general population of faculty.

In a first approximation ( $t$ test), the average difference was used to compare two faculty groups: faculty of color versus white faculty. While we know, for example, that African American faculty experiences may differ from Asian American faculty experiences, previous research has indicated that these differences are significantly less than for those between white faculty and faculty of color as an aggregate (Astin, Antonio, Cress \& Astin, 1997). Therefore, race/ethnicity in this analysis was dichotomized. 
To account for observed statistical differences between the racial/ethnic groupings that may be due to other sources of variation (e.g., gender, academic rank), the second order approximation (factorial ANOVA) analysis identified whether supplemental variables had significant predictive power. Thus, the prospect of conclusions being confounded was reduced.

\section{Qualitative Data}

While campus climate issues differentially affect faculty of color, any institutional change effort requires involvement of the broader communiry. Therefore, qualitative data were gathered from randomly selected individuals and from existing campus faculty groups. The total number of participants was 274 , distributed relatively equally across academic ranks and representing membership in each of the university's 15 colleges and professional schools, including over 80 departments (see Figure 7.2). As nored above, faculty of color (and women faculty) were purposefully oversampled in order to fully investigate their experiences of campus climate.

Figure 7.2

Demographics for Faculty Participants

\begin{tabular}{|c|c|c|c|c|c|c|c|}
\hline \multicolumn{8}{|c|}{ Gender } \\
\hline \multicolumn{3}{|c|}{ Women } & \multicolumn{2}{|l|}{ Men } & \multicolumn{2}{|c|}{ No Response } & \\
\hline \multicolumn{3}{|c|}{$214(78 \%)$} & \multicolumn{2}{|c|}{$59(22 \%)$} & \multicolumn{2}{|c|}{$1(>1 \%)$} & \\
\hline \multicolumn{8}{|c|}{ Race/Ethnicity } \\
\hline $\begin{array}{l}\text { White } \\
\text { (Non- } \\
\text { Hispanic) }\end{array}$ & Hispanic & $\begin{array}{c}\text { Asian } \\
\text { American/ } \\
\text { Pacific } \\
\text { Islander }\end{array}$ & $\begin{array}{c}\text { Native } \\
\text { American }\end{array}$ & $\begin{array}{c}\text { African } \\
\text { American/ } \\
\text { Black }\end{array}$ & $\begin{array}{l}\text { Multi- } \\
\text { Racial }\end{array}$ & Other & $\begin{array}{c}\text { No } \\
\text { Response }\end{array}$ \\
\hline $175(75 \%)$ & $20(9 \%)$ & $16(7 \%)$ & $3(1 \%)$ & $8(3 \%)$ & $5(2 \%)$ & $3(1 \%)$ & $3(1 \%)$ \\
\hline \multicolumn{8}{|c|}{ Academic Rank } \\
\hline $\begin{array}{c}\text { Full } \\
\text { Professor }\end{array}$ & $\begin{array}{l}\text { Associa } \\
\text { Profess }\end{array}$ & $\begin{array}{l}\text { Assis } \\
\text { Profe }\end{array}$ & $\begin{array}{l}\text { stant } \\
\text { essor }\end{array}$ & ecturer & Instructor & Other & $\begin{array}{c}\text { No } \\
\text { Response }\end{array}$ \\
\hline $58(25 \%)$ & $53(239$ & $50(2$ & $2 \%$ & $6(7 \%)$ & $3(1 \%)$ & $52(22 \%)$ & $1(>1 \%)$ \\
\hline
\end{tabular}

To ensure anonymity data do not include administrative groups.

Focus groups were formed from academic clusters and ranks according to gender and race/ethnicity (e.g., male full professors, female associate professors, men of color, women of color); 165 faculty participated in these focus groups. In addition, faculty from existing on-campus groups (e.g., the Association for 
Women Faculty, Faculty with Disabilities, Lesbian/Gay/Bisexual Faculty) and administrative groups (e.g., Academic Deans Council, Faculty Senate, President's Cabinet) were invited to participate since their insights and presence could prove instrumental in leveraging future change efforts. Sixty-eight faculty attended the discussion groups and 41 (21 men and 20 women) attended the administrative groups.

Participants were asked to address three general topics, guided by a semistructured interview protocol: 1) factors at the university that have contributed to faculty success, 2) factors that have hindered or impeded faculty success, and 3) ideas, strategies, and recommendations for change. Additional questions and probes further explored faculty perspectives and experiences. While some categories and themes from the protocol framed and organized the initial analysis, all existing and emerging themes from the data were checked and compared across academic field, rank, gender, race/ethnicity, focus group type, and discussion group type.

\section{Results}

Congruent with research objectives to investigate faculty experiences and identify strategies for institutional change, results are grouped according to Wilber's (1998) four-dimension organizational paradigm (shown earlier in Figure 7.1). Quantitative findings and qualitative comments illustrative of emergent themes in the data operationalize the conceptual framework and serve as the foundation for recommendations for organizational transformation and development. The findings are presented as follows: 1) individual beliefs, values, attitudes, and feelings; 2) individual behaviors; 3) institutional beliefs, values, attitudes, and feelings; and 4) institutional processes and practices.

It should be reemphasized that the interaction of individual beliefs and behaviors mutually shape institutional values and processes, so the differences are often not completely distinct. Still, since "reality is not something objective or external to participants" (Tierney, 1987, p. 64), it is perfectly congruent to use faculty perceptions of values, behaviors, and processes to understand the nature of an organization's culcure and environment.

\section{Individual Beliefs, Values, Attitudes, and Feelings}

Faculty were asked to indicate their feelings about interpersonal relationships with faculty colleagues and administrators. Faculty of color are significantly more likely than their white peers to be dissatisfied with their professional counterparts (see Table 7.1). In fact, satisfaction decreases as faculty of color 
move up in the academic ranks, where over $15 \%$ of faculty of color who are full professors are not satisfied with their collegial relationships. In contrast, over $75 \%$ of white full professors are satisfied or very satisfied with their professional relationships. This difference may be due, in part, to the attempts of faculty of color to address multicultural and diversity issues with their resistant white colleagues.

- "We're seen as being irrational because we are angry and emotional about inequities and discrimination. They just wish we would assimilate and be quiet."

TABLE 7.1

Individual Beliefs, Attitudes, Values, Feelings (in \%)

\begin{tabular}{|c|c|c|c|c|c|c|c|c|}
\hline & \multirow[t]{2}{*}{$\begin{array}{l}\text { White } \\
\text { Faculry }\end{array}$} & \multirow[t]{2}{*}{$\begin{array}{l}\text { Faculty } \\
\text { of Color }\end{array}$} & \multicolumn{2}{|c|}{$\begin{array}{c}\text { Full } \\
\text { Professor }\end{array}$} & \multicolumn{2}{|c|}{$\begin{array}{l}\text { Associate } \\
\text { Professor }\end{array}$} & \multicolumn{2}{|c|}{$\begin{array}{l}\text { Assistant } \\
\text { Professor }\end{array}$} \\
\hline & & & $\begin{array}{l}\text { White } \\
\text { Faculry }\end{array}$ & $\begin{array}{l}\text { Faculty } \\
\text { of Color }\end{array}$ & $\begin{array}{l}\text { White } \\
\text { Faculty }\end{array}$ & $\begin{array}{l}\text { Faculty } \\
\text { of color }\end{array}$ & $\begin{array}{l}\text { White } \\
\text { Faculty }\end{array}$ & $\begin{array}{l}\text { Faculty } \\
\text { of color }\end{array}$ \\
\hline $\begin{array}{l}\text { Satisfaction" } \\
\text { with faculty } \\
\text { colleagues }\end{array}$ & 71.7 & $\begin{array}{l}54.2 \\
\quad p<0.05\end{array}$ & 76.8 & 46.9 & 62.7 & 54.1 & 71.6 & 68.8 \\
\hline $\begin{array}{l}\text { Satisfaction" } \\
\text { with } \\
\text { administrators }\end{array}$ & 59.6 & $\begin{array}{l}38.1 \\
p<0.01\end{array}$ & 63.6 & 37.6 & 56 & 34.8 & 53.8 & 43.8 \\
\hline $\begin{array}{l}\text { Subtle } \\
\text { Discrimination } \\
\text { as a source of } \\
\text { stress"• }\end{array}$ & 4.8 & $\begin{array}{l}25.7 \\
p<0.01\end{array}$ & 3.6 & 28.1 & 7.3 & 17.4 & 4.2 & 33.3 \\
\hline
\end{tabular}

("satisfied or very satisfied, "extensive)

Nearly $60 \%$ of white faculty feel satisfied or very satisfied in their relationships with administrators. In comparison, about $25 \%$ of all faculty of color are not satisfied in their relationships with administrators. While it is unknown whether these administrators are upper-level managers or department chairs, faculty of color feel they do not have good working relationships with those who are in positions of leadership, power, and decision-making.

Further, faculty of color questioned the integrity of administrators and their commitment to diversity.

- "People tell you one thing and do another. Everything is spelled out in the books and yet the administration does exactly what they want."

- "The issues of governance and democratic practice in the faculty and administration aren't divorced from the issues for women of color. You 
actually have an undemocratic system. A network where decisions are made among friends. That's why it becomes very difficult for women of color to break into those decision making networks."

- "This university is still to me a white male university because that's what you see at most of the policy making positions and the idea of diversity doesn't even compute."

One in four faculty of color reported feeling "extensive" stress due to subtle discrimination (as compared to 1 in 20 white faculty). Nearly another one in four faculty of color report that they are somewhat distressed by subtle discrimination. Restated, half of all faculty of color experience some degree of stress due to subtle discrimination.

- "As minority faculty members we go through very polite discrimination. Someone said to me, 'I don't even think of you as Black."'

- "A white professor made a statement that women and minorities undermine the ranking of the university."

- "When 1 was coming up for tenure the acting chair wanted me to know that the dean said that there would be no preferential treatment, not for women and not for minorities. I was so shocked that I didn't react. What does that mean? That I am here because $I$ am a minority and a woman and not because of my qualifications. If I told this woman this is a racist statement, she would freak out. She is not aware of what she's saying. We need to find a way to sensitize people to the kind of casual comments that are really racist in a subtle manner."

In summary, when exploring individual beliefs, faculty of color feel less satisfied in their professional relationships with faculty colleagues and administrators and experience significant distress over subtle discrimination. As Wilber (1998) and others (e.g., Deci, Kasser, \& Ryan, 1997; Tierney \& Bensimon, 1996) have asserted, internalized feelings and attitudes are inextricably linked with excernalized bchaviors. These data are examined next. Specifically, the analysis focuses on the inclination of faculty to actively promote diversity in their classrooms as part of creating an inclusive campus climate.

\section{Individual Behaviors}

One of the most striking differences berween white faculty and faculty of color is in their teaching behaviors. Only $45 \%$ of white faculty, as compared to $67 \%$ of faculty of color, responded affirmatively that teaching to enhance students' 
knowledge and appreciation of racial/ethnic groups is essential or very important (see Table 7.2).

TABLE 7.2

Individual Behaviors* (in \%)

\begin{tabular}{|c|c|c|c|c|c|c|c|c|}
\hline & \multirow[t]{2}{*}{$\begin{array}{l}\text { White } \\
\text { Faculty }\end{array}$} & \multirow[t]{2}{*}{$\begin{array}{l}\text { Faculry } \\
\text { of Color }\end{array}$} & \multicolumn{2}{|c|}{$\begin{array}{c}\text { Full } \\
\text { Professor }\end{array}$} & \multicolumn{2}{|c|}{$\begin{array}{l}\text { Associate } \\
\text { Professor }\end{array}$} & \multicolumn{2}{|c|}{$\begin{array}{l}\text { Assistant } \\
\text { Professor }\end{array}$} \\
\hline & & & $\begin{array}{l}\text { White } \\
\text { Faculty }\end{array}$ & $\begin{array}{l}\text { Faculty } \\
\text { of Color }\end{array}$ & $\begin{array}{l}\text { White } \\
\text { Faculty }\end{array}$ & $\begin{array}{l}\text { Faculty } \\
\text { of color }\end{array}$ & $\begin{array}{l}\text { White } \\
\text { Faculty }\end{array}$ & $\begin{array}{l}\text { Faculty } \\
\text { of color }\end{array}$ \\
\hline $\begin{array}{l}\text { Teaching } \\
\text { knowledge and } \\
\text { appreciation of } \\
\text { racial/ethnic } \\
\text { groups }\end{array}$ & 44.9 & $\begin{array}{l}66.7 \\
p<0.01\end{array}$ & 39.8 & 67.8 & 52.5 & 58.3 & 48.4 & 76.5 \\
\hline $\begin{array}{l}\text { Promote racial } \\
\text { understanding }\end{array}$ & 48.8 & $\begin{array}{r}68.1 \\
p<0.01\end{array}$ & 46.9 & 71.0 & 49.3 & 63.7 & 53.2 & 68.8 \\
\hline
\end{tabular}

("essential or very important)

Similarly, over two-thirds of faculty of color assert that promoting racial understanding in their classrooms is very important or essential. Perhaps the good news is that nearly half of white faculty share this behavioral perspective. Accordingly, faculty of color state that failing to facilitate racial understanding undermines student success and the academic integrity of the institution.

- "There is a level of denial about the pervasive problems of race and ethnicity in this university. It can't be divorced from the retention rates for undergraduate students and graduate students. These things are all connected to each other. The reason that somebody could get away with not grooming you for the next level, this is the same reason we allow all the Native American kids to flunk out."

- "The institurion would like to have the appearance of diversity and multiculturalism while maintaining what the current faculty view as academic excellence. We're merely replicating the status quo. That is not true academic excellence."

The data evidence distinctive differences regarding attitudes and subsequent behaviors of individual faculty across race/ethnicity. As Wilber (1998) and Hurtado et al. (1998) suggest, group dynamics with respect to cultural norms and collective practices must also be examined to understand the degree of congruence or incongruence between individuals and the organization. Faculty perceptions of institutional norms and processes follow. 


\section{Institutional Beliefs, Values, Attitudes, and Feclings (Cultural Norms)}

The majority of faculty indicate that there is institutional support for their research agenda. However, faculty of color are less likely than white faculty to believe that their research is valued within their department. This particularly holds true at the full professor level. Interestingly, white associate professors hold similar views to their faculty of color counterparts regarding support for their research interests. Unfortunately, about one-third of these faculty and faculty of color feel alienated from their department due to their tesearch interests and choices (see Table 7.3).

TABLE 7.3

Institutional Beliefs, Attitudes, Values, Feelings

(Cultural Norms)* (in \%)

\begin{tabular}{lcccccccc}
\hline & $\begin{array}{c}\text { White } \\
\text { Faculty }\end{array}$ & $\begin{array}{c}\text { Faculty } \\
\text { of Color }\end{array}$ & \multicolumn{2}{c}{$\begin{array}{c}\text { Full } \\
\text { Professor }\end{array}$} & \multicolumn{2}{c}{$\begin{array}{c}\text { Associate } \\
\text { Professor }\end{array}$} & $\begin{array}{l}\text { Assistant } \\
\text { Professor }\end{array}$ \\
\hline & & & $\begin{array}{c}\text { White } \\
\text { Faculty }\end{array}$ & $\begin{array}{c}\text { Faculty } \\
\text { of Color }\end{array}$ & $\begin{array}{c}\text { White } \\
\text { Faculty }\end{array}$ & $\begin{array}{c}\text { Faculty } \\
\text { of color }\end{array}$ & $\begin{array}{c}\text { White Faculty of color } \\
\text { Faculy }\end{array}$ \\
\hline $\begin{array}{l}\text { Research } \\
\text { Agenda is } \\
\text { Valued }\end{array}$ & 78.4 & $\begin{array}{c}66.2 \\
\text { p<0.08 }\end{array}$ & 83.0 & 65.7 & 67.9 & 62.5 & 81.8 & 73.4 \\
\hline $\begin{array}{l}\text { A lot of racial } \\
\text { conflict present }\end{array}$ & 4.3 & $\begin{array}{c}14.1 \\
\text { P<0.01 }\end{array}$ & 3.2 & 15.6 & 6.9 & 12.5 & 3.4 & 13.3 \\
\hline
\end{tabular}

('agree or agree strongly)

Of grave concern to faculty of color was the dismissal of their work if it related to multicultural or feminist issues. Indeed, the value of diversity-related scholarship at the institution was in question.

- "Some of the reviewers for promotion are not aware of certain specialty presses. The same manuscript that was [initially] accepted by African World Press, which is very respected, at least in my field, was turned down because somebody saw my dossier and implied that all Black people support each other and publish each other's work. So I sene this same manuscript out to [another press] which accepted it and that is what facilitated the positive decision on my promotion."

- "In spite of the talk about diversity it doesn't permeate. It's not a category or a criterion that is at all respected or implemented or articulated at any level." 
Reinforcing these comments, a number of white faculty stated that they were so busy trying to survive themselves that they were unable to add "another initiative like diversity" to their "full plates."

- "We're so entrenched in just trying to get our day-to-day work done that looking to other kinds of things like diversity is difficult." (white female associate professor)

- "I just don't feel that diversity is honored here because we have this bureaucracy model. Anything that takes extra time is not going to be dealt with, which in all reality is actually antigrowth for the institution and for student learning." (white female faculty)

Like the contrasting views on institutional values and priorities related to multiculturalism, there is also differing opinion on how faculty of color and white faculty view racial conflict on campus. Faculty of color are significantly more likely than white faculty to agree that there are racial tensions.

- "I'm one of three Latino faculty in the whole college. It's not a priority and I'm the one trying to bring it to their attention. I can even feel very liberal faculty getting irritated with me. They get mad at me for bringing that up. Like how dare you. This is not something to consider. For them it's not a priority."

The culture of incivility described by faculty is likely related to earlier accounts of stress due to discrimination. Faculty highlighted exchanges where ideas were dismissed and faculty of color were left feeling voiceless and invisible.

- "I have heard from other colleagues who are Hispanic or African American that they have had students on campus talk to them in ways that $I$ wouldn't want to be talked to. There are people on the staff who have been insulting to them, faculty who have ignored them at meetings, who have dismissed what they wanted to do."

- "If you come with an idea, it's viewed as a small-disconnected idea. Then later, a white male wants to do this and it's a great idea. Everybody's going to do this. Whatever you suggest it's not particularly good. It's a constant hammering away at your intelligence and integrity."

Hence, the organizational culeure was depicted as resistant to multicultural efforts. Norms within colleges and departments appear to be reinforced through hostile and combative communications that uphold values for traditional forms of scholarship and competitive individualism. According to faculty of color, the 
resultant racial conflict plays into the hands of those in power as an age-old divide and conquer scheme that precludes the institution from making change. Given the existing climate, the only way to transform cultural norms is to directly address the institutional processes and procedures that reward such attitudes and behaviors.

\section{Institutional Processes and Practices}

When considering issues of race/ethnicity, female faculty of color voiced concern that their teaching load and expectations are especially heavy as compared to their colleagues.

- "I keep being told you really don't need to spend this much time working with students. We have a faculty member, a man, a white male in our department who really thinks that the only thing that you should count toward merit is publications. Not teaching or service. I think for many women teaching is an interpersonal connection that we value and the lack of university rewards is a difficult barrier to fight against all the time."

- "I find myself mentoring an inordinate number of students. I realize that I have come to be for these students somebody who will have a more understanding perspective on their problems, who will give them personalized attention. They assume because I am a woman of color I will be able to identify with some of their struggle. So I just don't see other Latino women students, I see the Native American students. I see the students with disabilities. I see African American students, all coming to me. It's an activity that I personally find rewarding but it does not translate in any way into the kinds of recognition of the service that I provide to the university."

Not surprising, then, faculty of color are significantly less likely than their white colleagues to believe that faculty of color are treated fairly on campus (see Table 7.4). Compared to almost $90 \%$ of white faculty who indicate that faculty of color are treated equitably, about half of all faculty of color do not share this perspective.

- "Quite frankly, if I want to move up I won't stay here. I've been told by white faculty on this campus that there is no administrative mobility for women of color. There is no pipeline or mentorship for women of color into administrative management." 
TABLE 7.4

Institutional Processes and Practices* (in \%)

\begin{tabular}{|c|c|c|c|c|c|c|c|c|}
\hline & \multirow[t]{2}{*}{$\begin{array}{l}\text { White } \\
\text { Faculty }\end{array}$} & \multirow[t]{2}{*}{$\begin{array}{l}\text { Faculty } \\
\text { of Color }\end{array}$} & \multicolumn{2}{|c|}{$\begin{array}{c}\text { Full } \\
\text { Professor }\end{array}$} & \multicolumn{2}{|c|}{$\begin{array}{l}\text { Associate } \\
\text { Professor }\end{array}$} & \multicolumn{2}{|c|}{$\begin{array}{l}\text { Assistant } \\
\text { Professor }\end{array}$} \\
\hline & & & $\begin{array}{l}\text { White } \\
\text { Faculty }\end{array}$ & $\begin{array}{l}\text { Faculty } \\
\text { of Color }\end{array}$ & $\begin{array}{l}\text { White } \\
\text { Faculty }\end{array}$ & $\begin{array}{l}\text { Faculty } \\
\text { of color }\end{array}$ & $\begin{array}{l}\text { White } \\
\text { Faculty }\end{array}$ & $\begin{array}{l}\text { Faculty } \\
\text { of color }\end{array}$ \\
\hline $\begin{array}{l}\text { Faculty of } \\
\text { Color } \\
\text { treated fairly }\end{array}$ & 87.2 & $\begin{array}{l}55.8 \\
\text { p<0.01 }\end{array}$ & 92.2 & 46.7 & 84.9 & $\$ 9.1$ & 74.4 & 68.8 \\
\hline $\begin{array}{l}\text { Women faculty } \\
\text { treared Fairly }\end{array}$ & 82.4 & $\begin{array}{c}71.0 \\
p<0.01\end{array}$ & 89.7 & 68.9 & 77.8 & 66.7 & 67.1 & 81.3 \\
\hline $\begin{array}{l}\text { Gay and Lesbian } \\
\text { faculty } \\
\text { treated fairly }\end{array}$ & 80.2 & $\begin{array}{c}63.3 \\
p<0.01\end{array}$ & 84.4 & 66.6 & 76.4 & 52.6 & 72.2 & 71.4 \\
\hline
\end{tabular}

("agree, agree strongly)

Not only do faculty of color perceive unfair treatment based upon race/ethnicity, but they affirm that faculty are treated unfairly based upon gender and sexual orientation. Faculty of color are less likely than white faculty to agree that women faculty and gay and lesbian faculty have the same opportunities as white faculty and heterosexual faculty.

\section{Discussion and Recommendations}

- "It's mind boggling when you think of all these intelligent and hard-working people and what could be accomplished if the barriers were removed."

Within the interviews, focus groups, and discussion groups, faculty shared their sentiments about the treatment and acceptance of various individuals and groups as a part of the campus community. They told heartbreaking stories of discrimination. They singled out examples of leadership and policies that create an inequitable work environment. They also expressed their belief in the critical historical juncture in which the institution is poised to either improve itself or face a new millennium as a disjointed and disconnected learning community.

Campus climate is not just about warm and fuzzy or hurt feclings. Instead, it is the lived experiences of faculty lives, which in turn has an impact on the academic excellence of the entire institutional community. Consistent with previous studies (Aguirre, 2000; Turner \& Myers, 2000), faculty of color frequently referred to themselves as the roken individuals. They spoke of the burdens of representing faculty of color on committees and the realities of increased advising 
loads since students of color often sought them out, whether or not they were their assigned adviser. Supporting existing scholarship (Brown, 2000; Finkelstein et al., 1998; Garcia, 2000; Padilla, 1994; Turner, 2002), faculty of color noted feeling marginalized and culturally taxed, having less opportunity to pursue their own research and scholarly interests, and having their work devalued by majority faculty. These factors often resulted in increased stress and diminished job satisfaction (Astin, Antonio, Cress, \& Astin, 1997). Unfortunately, the outcome of raising issues of inequity and diversity can result in negative career consequences if faculty of color challenge existing social and organizational structures within the university (Foster, 1989; Giddens, 1984; Tierney, 1997; Tierney \& Bensimon, 1996).

Given that positional leaders and those with decision-making authority at the university are primarily senior-level white males, their ability to empathize with faculty of color experiences may be limited. Since most individuals tend to act and behave according to their beliefs and feelings (Wilber, 1998), white faculty may be more likely to devalue the experiences of faculty of color since their perceptional realities are different. Fortunately, faculty of color are not completely alone in their concerns. For instance, one white male faculty commented:

- "The kinds of things that are the result of the lack of a salary structure and individual initiative based salary negotiating actually do magnify gender and ethnicity related inequities. To the extent that those behaviors may be asymmetric over gender and ethnic background you're going to end up getting gaps that get widened."

Creating positive institutional change will only occur if members of the institution work together toward common goals. Moreover, understanding the organizational context utilizing Wilber's framework can facilitate effective change efforts by addressing individual and institutional dimensions.

For example, specific recommendations for changing the institution emerged directly from the faculty themselves. They spoke of creating humanitarian alliances across departments and disciplines, developing mentor programs for faculty, providing leadership and professional development opportunities for faculty of color, and adjusting the reward system to value teaching and research focused on diversity and multicultural issues.

In particular, faculty of color fele that there needs to be specific incentives and disincentives if "real" and "tangible" institutional transformation is going to occur. They felt adamant that positive change would not occur spontaneously and that faculty and administrators need to be held accountable for 
their efforts. Faculty of color did not suggest creating quotas, but that "progress benchmarks" regarding diversity issues could be defined by faculty within individual departments as well as across schools with specific monetary and promotional consequences tied to the outcomes. As one faculty member stated:

- "How do we make the importance of people of color a priority among competing priorities? How do we express or communicate the need in a larger national interest that students in the pipeline will effect our very own survival? You must make it part of the promotion and tenure process. Part of the renewal of contracts for administrators. We have to provide perks in terms of financial support for this kind of implementation to make it worth their while. Right now they're not getting anything out of giving their time to help somebody else. Male or female, Black or White, Asian or Hispanic."

As a result of the data and faculty recommendations for change, the project constructed a series of action initiatives intended to improve the university across multiple dimensions of the organization and which address the interaction of individual values and behaviors with organizational norms and processes. The recommendations are strategies intended to influence values, behaviors, and organizational procedures in order to enhance the campus work and learning climate for academic excellence.

\section{Strategy 1. Create Networking Opportunities for Faculty of Color}

- Create a faculty mentoring program that would encourage application from interested mentors who would be supported in their mentoring roles by resources in their units and would receive additional compensation from the provost's office for their efforts.

\section{Strategy 2. Integrate New Forms of Scholarship Into Promotion and Tenure Processes}

- Educate promotion and tenure and search committees about the criteria for newly emerging rescarch arcas (c.g., feminist, race/ethnicity studies, sexuality studies, community based and applied research) and about mulriple models for faculty success.

- Given the difficulty of achieving blind review through all performance review processes, develop a second-look review mechanism for faculty of color to ensure fair treatment of individuals in these groups. 


\section{Strategy 3. Monitor distribution of resources and Teaching/Advising Loads}

- Establish an annual departmental reporting process to compare faculty teaching and service responsibilities. Pay particular attention to the workload for faculty of color, recognizing the burden of informal advising assumed by those faculty.

- Develop a college-based system of rewards, including compensatory release time and research support for faculty with extraordinary teaching and service responsibilities.

- Make internal resources for research and faculty development activities equally visible and available to all.

\section{Strategy 4. Offer Leadership Opportunities for Faculty of Color}

- Make each college and its dean accountable for increasing the numbers of faculty of color in leadership positions.

\section{Strategy 5. Address Subtle Discrimination}

- Make clear that subtle discrimination and other disrespectful behavior will not be tolerated at any level, and require administrators to take this into account for all evaluations and merit raises.

- Require training for all deans, department heads, and directors on a continuing basis, to prevent all forms of discrimination. Encourage administrators to educate their faculty in turn.

- Thoroughly investigate patterns of complaints against any administrator and discipline discriminatory administrators, removing them from positions of leadership if necessary.

\section{Conclusion}

Variability of experience exists from individual to individual. It is imperative, then, that we forgo stereotyping any faculty member by their affiliation with certain categorical groupings. Still, the fact remains that white faculty and faculty of color experience the institution quite differently. If we are to fully understand institutional impediments in faculty lives, we must take into consideration how faculty construct and make meaning of their experiences. For instance, what may appear to one faculty as a jovial or jocular remark, may 
appear to another faculty as a comment of ridicule. The co-mingling of these independent realities is what embodies faculty's daily working lives. If we fail to bring into consciousness the possibility of multiple interpretations of experience and the multiple dimensions that comprise an organization, we replicate and reinforce inequities and domination that inevitably get subsumed into the practices of our teaching, service, and research.

Further, as Wilber (1998) suggests, we can only leverage institutional change when we recognize the dynamic interdependence of individuals and organizations. To facilitate organizational transformation, we must validate individual feelings, reward (or sanction) individual behaviors, make explicit organizational culture (with respect to institutional goals and mission), and align organizational practices with institutional vision.

Faculty of color believe from their experiences and interactions that, at the very least, critical information, knowledge, and decisions are often withheld from them. Further, some faculty of color believe that their marginalization in the institution is based on active and intentional prejudice, since their race/ethnicity (and at times their gender or sexual orientation) is dissimilar from those in leadership positions. What this means for the institution is that alternative approaches to problem solving and creative initiatives are stifled, recruitment and retention of diverse faculty remain problematic, career progression is delayed or denied, and the overall climate is pervasively chilly. While the findings from this study are specific to one institution, the strategies offered here are adaptable to any organization that is genuinely committed to diversity. We hope that these insights into the academic lives of faculty of color and their specific recommendations for change will ultimately lead to equitable working and learning environments for the entire academic community.

\section{ReFERENCES}

Aguirre, A., Jr. (2000). Women and minority faculty in the academic workplace: Recruitment, resention and academic culture (ASHE-ERIC Higher Education Report, 27(G)). San Francisco, CA: Jossey-Bass.

Antonio, A. L. (2002). Faculty of color reconsidered. Retaining scholars for the future. Journal of Higher Education. 73(5), 582-602.

Astin, H. S., Antonio, L. S., Cress, C. M., \& Astin, A. W. (1997). Race and ethnicity in the American professoriate, 1995-96. Los Angeles, CA: Higher Education Research Institute, University of California Los Angles. 
Astin, H. S., \& Cress, C. M. (1998). A national profile of women faculty in research universities. Invitational Conference at Harvard University, Committee for Gender Equity, Cambridge, MA.

Astin, H. S., \& Cress, C. M. (2002). Women faculty transforming research universities. In L. S. Hornig (Ed.), Equal rites, unequal outcomes: Women in American research universities (pp. 53-88). New York, NY: Kluwer.

Brown, M. C. (2000). Involvement with students: How much can I give? In M. Garcia (Ed.), Succeeding in an academic career: A guide for faculty of color (pp. 71-88). Westport, CT: Greenwood Press.

Creamer, E. G. (1998). Assessing faculty publication productivity: Issues of equity (ASHEERIC Higher Education Report, 26[2]). Washington, DC: George Washington University, Graduate School of Education and Human Development.

Deci, E., Kasser, T., \& Ryan, R. (1997). Self-determined teaching: Opportunities and obstacles. In J. Bess (Ed.), Teaching well and liking it: Motivating faculty to teach effectively (pp. 57-71). Baltimore, MD: Johns Hopkins University Press.

Finkelstein, M. J., Seal, R. K., \& Schuster, J. H. (1998). The new academic generation: A profession in transformation. Baltimore, MD: Johns Hopkins University Press.

Foster, W. (1989). Toward a critical practice of leadership. In J. Smyth (Ed.), Critical perspectives on educational leadership (pp. 39-63). London, England: Falmer Press.

Garcia, M. (2000). Succeeding in an academic career: A guide for faculty of color. Westport, CT: Greenwood Press.

Giddens, A. (1984). The constitution of society. Los Angeles, CA: University of California Press.

Higher Education Research Institute. (1999). The American college teacher: National norms for 1998-99 HERI faculty survgy. Los Angeles, CA: University of California.

Hurtado, S., Milem, J. F., Clayton-Pedersen, A. R. \& Allen, W. R. (1998). Enhancing campus climates for racial/ethnic diversity: Educational policy and practice. Review of Higher Education, 21(3), 279-302.

Laden, B. V., \& Hagedorn, L. S. (2000). Job satisfaction among faculty of color in academe: Individual survivors or institutional transformers? In L. S. Hagedorn (Ed.), New directions for institutional research: No. 105. What contributes to job satisfaction among faculty and staff (pp. 57-66). San Francisco, CA: Jossey-Bass.

O'Meara, K. (2002). Uncovering the values in faculty evaluation of service as scholarship. Review of Higher Education, 2Q1), 57-80. 
Padilla, A. M. (1994). Ethnic minority scholars, research, and mentoring: Current and furure issues. Educational Researcher, 23(4), 24-27.

Tierney, W. G. (1987). Facts and constructs: Defining reality in higher education organizations. Review of Higher Education, 1/(1), 61-73.

Tierney, W. G. (1997). Organizational socialization in higher education. Journal of Higher Education, 68(1), 1-16.

Tierney, W. G., \& Bensimon, E. M. (1996). Promotion and tenure: Community and socialization in academe. Albany, NY: State University of New York Press.

Tierney, W. G., \& Rhoads, R. A. (1993). Enhancing promotion, tenure and beyond: Faculy socialization as a cultural process (ASHE-ERIC Higher Education Report No. 6). Washington, DC: George Washington University.

Turner, C. S. V. (2002). Women of color in academe: Living with multiple marginality. Journal of Higher Education, 73(1), 74-93.

Turner, C. S. V., \& Myers, S. L., Jr. (2000). Faculty of color in academe: Bittersweet success. Needham Heights, MA: Allyn and Bacon.

Turner, C. S. V., \& Thompson, R. J. (1993). Socializing women doctoral students: Minority and majority experiences. Review of Higher Education, 1Q3), 355-370.

Wilber, K. (1998). The marriage of sense and soul: Integrating science and religion. New York, NY: Random House. 